\title{
LITERATURA COMO TRABALHO E APROPRIAÇÃO
}

\author{
Prof. Dr. Hermenegildo Bastos (UnB)
}

RESUMO: As notas de pesquisas aqui apresentadas dizem respeito à interpretação como forma de apropriação. A literatura é trabalho de linguagem, também uma forma de apropriação, mas tem sempre uma dimensão política porque se opõe ao trabalho alienado. A arte relembra ao homem que a liberdade é o seu destino como espécie.

PALAVRAS-CHAVE: Poesia; linguagem; apropriação.

\begin{abstract}
The bulk of research notes herein introduced concern themselves to the interpretation as a form of appropriation. The literature is work of language, a type of appropriation too, but has always a politic al dimension because it is the opposite to the alienated work. Art reminds to the man that the liberty is our destiny as a species.
\end{abstract}

KEYWORDS: Poetry; language; appropriation.

Nosso ponto de partida é a mimese enquanto atividade, não como imitação passiva. A representação literária do mundo é um fazer, ou produção, ou ainda, poesia. Já em Aristóteles, o que importa são os modos de representar, não alguma coisa estática que, por estática, permitisse ser copiada. Nem por isso a obra se fecha em si mesma, mesmo porque os modos de representar, como, por exemplo, os gêneros, são históricos.

A poesia imita as ações humanas. Imitar é, então, também conhecer o devir dos significados que recairão sobre as ações; ou reconhecer, mas não como se os significados já lá estivessem desde sempre postos, porque significar é transitivo, é dar significado. A imitação poética é um processo.

É no trabalho artístico, nos modos de como se constrói a representação, que se dá o processo mimético. A obra literária (que é exatamente isso - opus) exigirá do seu intérprete que encontre o mundo na forma. A sociedade, que por si mesma é já também uma forma, só se deixará apreender na e pela forma da obra.

A hermenêutica marxista traz uma herança aristotélica. Os homens agem sobre a natureza e transformam-na, dizemos. O trabalho é o metabolismo homem/ natureza. A rigor é poético. Mas, no processo, as relações humanas - dos homens com a natureza e entre si - vêm a ser cada vez mais complexas. 
O trabalho artístico, como diz Marx e, na esteira dele, Lukács, é paradigma do trabalho livre. $^{1}$

O trabalho poético contradiz o trabalho estranhado que, como produto que se reproduz indefinidamente, amplia infinitamente a reificação. A contradição não dá à obra uma presunçosa superioridade: o sentido está no saber (internalizado nela) de que também ela habita o mundo reificado, pois só assim ela pode verdadeiramente contradizer. Esta é a primeira contradição - haver arte. A arte contradiz, recusa a sociedade da mercadoria.

Cabe interpretar a contradição como um fenômeno histórico, porque não existe desde sempre. A literatura (a arte) é um gesto de corte no sistema da divisão moderna do trabalho, embora não possa ser entendida fora dele. Os leitores vão reencontrar o gesto na configuração da obra, ou ainda mais, como constitutivo do texto enquanto literário e diferenciador de outros textos.

Este é o sentido primeiro de que os demais decorrem. Antecede a toda hermenêutica literária, porque só a partir dele existe literatura.

As relações entre obra e mundo estarão no centro das nossas discussões. A interpretação não é um ato externo a essas relações. Interpretar é ativar sentidos que estão na obra, é "apropriar hic et nunc a intenção do texto" (Ricoeur, 1970, p. 198). Ao intérprete cabe manter uma posição crítica, mas sem que isto lhe impeça de acercar-se do texto como "palavra atual" (Ricoeur, idem, p. 194). A interpretação torna próprio (apropria) o que era alheio; atualiza, assim, as possibilidades semânticas de um texto.

Falamos de saber internalizado no texto, sabendo, contudo, que o que se tem acentuado mais recentemente é ou o inconsciente ou simplesmente o giro dos significantes que se sucedem uns aos outros sem significado último possível.

A obra é autoconsciência da sociedade porque revela a sociedade a si mesma, evidencia tudo aquilo que a sociedade procura ocultar. A literatura é reconhecimento, ou anagnórisis, ela mesma sendo uma espécie de sujeito.

\footnotetext{
1 - Ver sobre isso Marx (2004), Prawer (1978, p. 46), Eagleton (1993, p. 152), Lukács (1972, p. 329), Vázquez (1978).
} 
Para Eagleton o que "emerge (...) no final do século XVIII, é a curiosa idéia da obra de arte como uma espécie de sujeito.” (1993, p. 9) Não é o artista o sujeito, mas a obra. Da maneira como ela articula os diversos setores da vida social e individual decorre a sua condição de sujeito. Ela pensa a sociedade na mesma medida em que lhe dá coesão pela sensibilidade.

Subjetividade do escritor ou objetividade do material trabalhado? - o nosso projeto é tentar esboçar uma saída para este dilema, com base no conceito de apropriação (Aneignung), entendida como ação da obra e também da sua interpretação.

Quanto ao papel e força do inconsciente, não vemos aí uma contradição insuperável. Jameson fala de "inconsciente político" como o nondit ou impensé. (1992, p. 44) O texto procura em vão controlar as contradições sociais. A impossibilidade de controlar abre o caminho para interpretar a obra.

Jacques Rancière, por sua vez, trabalha com a noção de inconsciente estético: as figuras literárias e artísticas escolhidas por Freud servem para provar que há sentido aí onde parece não haver, ou enigma no que aparentemente se basta a si mesmo, ou uma força de pensamento no que parece ser um detalhe anódino. Elas testemunham a relação entre o pensamento e o não-pensamento, ou certo modo de presença do pensamento na materialidade sensível, do involuntário no pensamento consciente e do sentido no insignificante. (2001, p: 9 e ss.)

As correntes de pensamento segundo as quais é impossível (e indesejável) chegarse a um sentido - sentido que acenaria perigosamente para uma totalidade e, por essa via, para o totalitarismo, não conseguem solucionar um paradoxo colocado pela sua própria negação: a impossibilidade de sentido é um fenômeno das obras pós-modernas, não é um fenômeno dos séculos XIX e XX. Vale a pena tentar entender a diferença. Se este é um fenômeno circunscrito a um momento histórico específico, isto não é por si mesmo um sentido? Como um fenômeno próprio a sociedades altamente complexas, nas quais os homens se veem como átomos sem ligação com o mundo real, ele não é uma simples ilusão. Este, o paradoxo: se o tomamos como ilusão, o desqualificamos; se como realidade, ele faz sentido.

A hermenêutica de que se falará e se praticará aqui é marxista. Não entendemos que o sentido da obra deve ser procurado fora dela. Muitas obras representam o trabalho 
humano, a exploração, a dominação do homem e da natureza, mas tudo isto passa a ser significante quando visto na perspectiva do trabalho do próprio escritor, que é produtor de sentidos.

Se o poema inicia por um "Fabrico um elefante/ de meus poucos recursos. Um tanto de madeira/ tirado a velhos móveis/ talvez lhe dê apoio." (Drummond, 1967, p. 168), o leitor será levado a figurar o elefante, o que ele simboliza enquanto doçura e carência no "campo de batalha". Há aí referências a elementos do trabalho artesanal algodão, paina, flores de pano. Mas só será leitor aquele que souber de antemão que a fabricação é fictícia, operando um deslocamento dos sentidos. "Fabrico" remete a fábrica, e afinal "O elefante" é um poema de A rosa do povo, livro da "militância literária" de Drummond. Mas, na fábrica, a produção é impessoal, diferentemente do artesanato, em que o trabalhador deixava suas marcas. O poeta fala de seu trabalho, ou da poesia como trabalho, dos "poucos recursos". A arte identificada com o circo, o jogo, a infância, oposta ao "mundo enfastiado" da cidade.

Afirma Jauss (1994, p. 146) que não conhece poema sobre o mar mais grandioso e harmonioso do que "Le cimetière marin" de Valery. Isto se dá porque o poema não fala do mar, faz-nos esquecer seu objeto e admirar seu procedimento, a produção do texto inscrita no texto. Seguramente deveria acrescentar que a poiesis constitui-se, assim, na forma mais poderosa de mimesis.

A leitura atualiza um sentido do poema. O "Amanhã recomeço" do último verso de Drummond é já um recomeçar, com o que se mantém viva a contradição entre trabalho poético e trabalho estranhado.

\section{HERMENÊUTICA DA MODERNIDADE}

A hermenêutica que vem de Schiller e chega a Freud e Marcuse localiza a divisão de trabalho no funcionamento interno da mente, nos modos de sentir e pensar, enfim, nos modos estéticos da vida. (Jameson, 1985, pp: 73 e ss.)

A tomada de poder pela burguesia só se consolidou com a criação do estético como reino à parte. Como observa Eagleton (1993, pp: 7 e ss), o estético como reino dos sentidos, da sensibilidade, propiciou à burguesia condições de construir sua 
hegemonia. Contudo é o estético mesmo que pode ameaçá-la: o mundo da sensibilidade, do corpo, ameaça sempre o poder constituído.

Eis a história da literatura moderna, crítica e autônoma. A obra literária moderna se desdobra necessariamente numa reflexão sobre o seu próprio trabalho. A literatura se volta sobre si mesma, não porque o mundo deixou de existir, mas porque a existência do mundo tornou-se problemática, ou seja, politizou-se.

A literatura se distanciou do mundo porque se fez crítica. Ela é, pois, a antítese da sociedade moderna, capitalista, a da forma-mercadoria, que reduz a natureza e os homens a coisas. O prazer que nos transmite a arte surge da compreensão de que um mundo outro é possível - o da liberdade. Enquanto o mundo da liberdade não existe, a arte é um consolo, um substituto, um sintoma, ou uma recusa? É necessário que o leitor tenha a chave para ativar uma dessas possibilidades e, assim, compartilhar a liberdade no efêmero da obra.

A auto-reflexão também não se reduz ao pensamento do personagem ou do narrador, aponta para as marcas do trabalho que, enquanto se desenvolve, pensa a si mesmo. Em alguns casos, a reflexão é a tônica da obra, mas, independentemente disso, o gesto produtivo não se completa enquanto não se volta sobre si mesmo. Em qualquer objeto produzido pelo homem estão inscritas as marcas do trabalho, mesmo nas sociedades em que predomina o trabalho estranhado.

$\mathrm{Na}$ literatura moderna os personagens e seu trabalho são do mundo do trabalho abstrato. Lemos a obra, e, inscritas nela, as marcas da sua produção. A obra é trabalho de signo. Ao lado disso, a sua recepção também produz significados. Daí a sua qualidade essencialmente política, mesmo porque os significados são literários, gozam de uma condição ao mesmo tempo de inferioridade e superioridade. Inferiores porque não são científicos; superiores porque são "sagrados". Tomar uma prática discursiva como superior a outra é por si mesmo uma opção política: quem diz a verdade? a partir de onde? e de que modo?

Literatura moderna, ou crítica, é autônoma. Autonomia é a maneira pela qual se estabelecem, na modernidade, os liames entre literatura e sociedade. Segundo Jameson, a pergunta pela autonomia deve ser substituída pela questão de "como a literatura veio a ser autônoma”, ou seja, como a literatura gradualmente se distanciou para organizar-se 
em um bloco de palavras relativamente auto-suficiente que pode ser apropriado por grupos e indivíduos rigorosamente separados uns dos outros no tempo e no espaço e por classe social ou cultura. $(1989$, p. 115)

A arte autonomizada assinala um desacordo próprio ao capitalismo entre a produção desde então chamada cultural e a material. Nas sociedades modernas, altamente complexas, a conexão entre as duas áreas da produção se "apaga", nem por isso deixa de existir.

A mimese como apropriação problematizou-se ao entrar na modernidade. Agora a obra literária se oferece como um acinte, ao impor-se como ficção pura e simplesmente. Modernamente, literatura é o que não é mito, ao mesmo tempo em que não é ciência: é apenas isto - ficção.

Assumir-se como ficção, como fingimento, não é, entretanto, algo pacífico. Significa antes de tudo compartilhar do racionalismo moderno. A literatura moderna é racionalista porque contemporânea da época em que predomina o conhecimento científico. Assumir-se como ficção é assumir-se como não-verdade, o que resulta em "inferioridade" como dissemos, mas também em questionamento da "inferioridade" e do princípio de verdade de que ela decorre. Questionando o predomínio do conhecimento científico, a literatura, entretanto, não se coloca como alternativa a ele: exige um conhecimento outro, assinala a ideologia contida no conhecimento tomado como verdade. A literatura moderna é, assim, a que questiona o conhecimento estabelecido, evidenciando a condição ideológica de toda "verdade".

Assumir-se como ficção é também demarcar uma fronteira - entre literatura e realidade. A demarcação é acintosa porque aí onde está "fícção" deve-se ler "nãorealidade". Não é tão visível, contudo, que "ficção" é a provocação do ponto de vista: a pluralidade de pontos de vista não suprime a realidade, pergunta quem a vê e com que interesses. A literatura é, então, uma provocação, um acinte (no sentido da expressão latina: a scinte, a sciente, o que é praticado de caso pensado, com o fim de provocar). $\mathrm{O}$ acinte é o gesto que desloca a linguagem do campo pragmático para o da ironia, sem que, entretanto, a linguagem deixe de comunicar. Interpretar é antes de tudo lidar com o acinte, pôr-se diante dele, pactuar.

Lendo "A realidade e a imagem" de Bandeira (1967, p. 330), o leitor se 
perguntará o que aí fazem as quatro pombas que passeiam. Sim, porque se entendemos que elas apenas passeiam, o "apenas" será o signo de outra ação que não a de passear. $\mathrm{Na}$ verdade escancaram o seu desdém perante toda determinação. O poeta poderia dizer apenas isto: "quatro pombas passeiam", mas preferiu fingir um espaço exterior onde isso ocorreria. A poesia é este acinte.

\section{O TRABALHO POÉTICO}

Centramos nossas investigações no trabalho artístico, não no "sujeito criador". Isto não significa, porém, que compartilhemos das idéias sobre a morte do autor desenvolvidas por Barthes, Foucault e outros. A ideia de apropriação abre uma perspectiva outra. Pelos atos de apropriação sujeito e objeto se constituem. Pela obra literária, compreendida como apropriação tanto do mundo quanto da tradição, constituem-se o sujeito (autor) e o objeto apropriado. Assim, autor (sujeito) e objeto não existem antes da obra. Nem por isso o autor deixa de existir, e não apenas como uma função jurídica de certos textos. Ele é um agente de apropriação.

Anteriormente falamos do saber internalizado na obra, de cuja tradição o escritor se apropria. O resultado dessa apropriação é produção de significado. Para as estéticas de filiação romântica, isto dependeria da genialidade do autor, da sua subjetividade. Sem querer negar o papel que o sujeito-escritor tem como agente de apropriação, é preciso salientar o papel que tem o objeto apropriado. Os códigos estético-literários legados pela tradição têm existência objetiva. Eles estabelecem limites, inclusive ao que é ou não considerado artístico.

A ideia de criatividade pressupõe que uma obra é superior a outra, um escritor superior a outro. Há relativa verdade nisso. Quando comparamos vários escritores de uma mesma época, escritores que trabalharam, portanto, com base no mesmo legado objetivo, não podemos fugir aos juízos de valor. Mas isso significa que os problemas deixados pela tradição encontraram resposta, foram equacionados pela obra ou pelo escritor relevante.

Enquanto interpreto a obra, acompanho o escritor no seu trabalho. Assim é imprescindível não tomar a obra como feita, como produto. Precisamos estar presentes outra vez no momento renovado da produção. É claro que o leitor pode tomar a obra 
como produto, no sentido de coisa fechada. Entretanto, acompanhar o processo que leva à obra é revelador das energias despendidas, da luta do escritor que vai se concretizando em palavras, frases, imagens, das suas escolhas, assim como dos limites impostos pela tradição.

A noção de apropriação ajuda-nos a entender o processo histórico da tradição literária e da localização, nela, do escritor individualmente considerado. Weimann (1983) não entende "apropriação" como algo limitado às ideias jurídicas de propriedade privada. "Apropriação" denota uma atividade que não se reduz aos atos de uma consciência histórica ou de um sujeito. Voltaremos a isso.

Como forma de trabalho, a literatura não pode ser entendida fora do processo de divisão do trabalho das sociedades modernas. A obra literária é uma forma específica de trabalho intelectual: o trabalho com a linguagem.

Esse tipo de trabalho traz à tona algo que, como membros de sociedades complexas como são as sociedades capitalistas, "esquecemos" (ou recalcamos): a linguagem como trabalho. Não há forma de trabalho em que não esteja envolvida a linguagem. Ao mesmo tempo, inclusive a linguagem interior ou as formas complexas da consciência só se tornaram possíveis a partir da evolução do trabalho.

A hermenêutica dialética não defende a tese da anterioridade do trabalho sobre a linguagem, mas sim a da simultaneidade: trabalho e linguagem são indissociáveis, ainda que possam e devam ser considerados dialeticamente como diferentes. Para Lukács, pelo trabalho o homem dá o salto para a condição propriamente humana. O trabalho é o fenômeno original - Urphänomen. Do trabalho surge a relação sujeito-objeto e o distanciamento do objeto frente ao sujeito, que cria de imediato uma base imprescindível, dotada de vida própria, para o ser social dos homens: a linguagem. $\mathrm{Na}$ linguagem, como no trabalho, consumou-se o salto do ser natural ao social. Lukács retoma Marx quando este, em A Ideologia Alemã, afirma que a linguagem é a consciência imediata do homem.

A instrumentalização da linguagem não é uma invenção do marxismo. Ela é parte da sociedade em que predomina o trabalho estranhado.

Quanto ao trabalho poético, que tampouco está fora do processo de reificação, dizemos que ele desenvolve a contradição entre a linguagem como instância da 
reificação e o seu questionamento. Como tal, a poesia é em primeiro lugar nostalgia do trabalho não alienado, de quando a linguagem ainda não estava moldada pelos padrões lógico-racionais, cujo modelo é o dinheiro como signo abstrato e universal: a racionalidade da linguagem pressupõe a racionalidade da economia mercante. (Lefebvre, s/d, p. 312) Mais ainda do que nostalgia, a poesia pode se construir como recusa, projetando-se, assim, como memória do futuro.

A forma é a linguagem da literatura. O trabalho abstrato, por sua vez, não possui nem qualidade nem forma, senão a que lhe é dada pela máquina. O trabalho artístico, apesar de alguns esforços teóricos e práticos no sentido oposto, não pôde identificar-se com o trabalho estranhado. Como tal, ele é obrigado a permanecer outro e diferente: se se tornasse igual, simples e não diferenciado, não seria forma. As condições do mundo capitalista predispõem, assim, a arte para uma situação anômala.

Segundo Asor Rosa (1989), a arte, ao recusar certas leis dominantes da produção capitalista, vende forma a quem não possui forma, liberdade a quem não tem liberdade, individualidade a quem não tem individualidade.

No seu trabalho, o escritor dispõe de relativa liberdade na escolha das técnicas de produção, o que, em condições normais, não se dá, uma vez que aos trabalhadores não é dada nenhuma escolha, cabendo-lhes trabalhar do modo que interessa àqueles que detêm os meios de produção. Ao trabalhar, o escritor assume o "privilégio" como uma marca da reificação. Ao mesmo tempo, sua relativa liberdade acena com a possibilidade de superar o mundo da reificação. O trabalho literário é, assim, ao mesmo tempo, amaldiçoado porque lembra ao homem, pelo revés, a sua falta de liberdade, mas também um espaço da memória (ou nostalgia) da liberdade.

Lukács dedicou substancial parte da sua obra à discussão da especificidade do trabalho estético. Localiza-a na suspensão temporária das finalidades práticas. Só no estético existe uma relação sujeito-objeto autêntica. A arte é a forma mais perfeita que assumiu essa relação. Ela é, nessa medida, a prova de que a liberdade é o nosso destino como espécie.

“Toda produção, diz Marx, é apropriação da natureza pelo indivíduo, no interior e por meio de uma determinada forma de sociedade.” (1970, p. 252). Por apropriação deve-se entender tanto as formas jurídicas de propriedade como a efetivação prática dos 
direitos. (Godelier, 1986, p. 19).

O discurso é também um objeto de apropriação. O seu estudo como objeto jurídico (como proposto por Foucault em “O que é um autor”) deve ser completado pelo seu estudo como sujeito de apropriação, isto é, como agências históricas de conhecimento, prazer, energia e poder (Weimann, 1992, p. 94). Em outras palavras: o discurso deve ser estudado não apenas em relação ao valor de troca da obra de um autor, isto é, seu status de propriedade (apropriação de texto), mas também, e ao mesmo tempo, em termos de seu valor de uso, isto é, com referência às funções e efeitos variáveis da sua produção literária como uma agência de apropriação (apropriação do mundo). Assim, tanto o mundo no livro quanto o livro no mundo são apropriados através de atos de aquisição intelectual e assimilação imaginativa nos níveis da escrita e da leitura.

\section{O ESTÉTICO E A HEGEMONIA}

O conceito básico é aqui o de modo de produção. Designa a maneira como está organizado e se desenrola o processo de produção das condições materiais de existência dos homens. Trata-se, portanto, em primeiro lugar, da produção material, mas o conceito abrange também as superestruturas. Como observa Godelier, nos inúmeros momentos em que trabalha o conceito de modo de produção, "Marx parece distinguir as condições materiais que constituem a base deste e as relações de produção que constituem a sua forma social”. (Godelier, Opus Cit., p. 69). Mas, compreendê-los como distintos é procurar captar a dialética que há neles.

A expressão infra-estrutura/superestrutura pode levar, pela qualidade de metáfora espacial, a um dualismo com a idéia subjacente de que a infra-estrutura determina a superestrutura de modo mecânico, o que é estranho ao pensamento de Marx. (Sobre os vários sentidos que "determinar" (bestimmen) assume na obra de Marx, ver Williams, Raymond, 2005 e 2007).

No conceito gramsciano de bloco histórico, reencontramos o pensamento de Marx e Engels: a produção humana, seja material, seja espiritual, é produção para o poder, na história concreta onde os dois níveis (infra-estrutura e superestrutura) convergem. Ressalve-se que, se há convergência, ela não deixa de ser dialética. Estrutura e 
superestrutura são conceitos válidos, mas só podem ser entendidos de modo dialético. A infra-estrutura separada do momento histórico concreto, abstraída, não existe. Não é uma realidade exterior à história.

Em Marxismo e literatura, Raymond Williams, em análise acurada do binômio infra-estrutura/superestrutura, e depois de passar por noções como 'mediação' e 'homologia', chega à noção gramsciana de hegemonia. (Williams 1979; cf. também 2005). "Hegemonia" vai além de "cultura" porque relaciona o processo social como totalidade. Vai além também de "ideologia" porque nela o decisivo não é apenas o sistema consciente de ideias e crenças, mas todo o processo social vivido. É todo um conjunto de práticas e expectativas sobre a totalidade da vida: nossos sentidos e distribuição de energia, nossa percepção de nós mesmos e de nosso mundo.

A estrutura e a superestrutura formam, quando o poder é hegemônico, um bloco histórico - afirma Gramsci (1975, p. 47). A realidade de qualquer hegemonia é a de que, embora por definição ela seja dominante, jamais será total ou exclusiva. Ela precisa ser reproduzida a cada dia, e no seu interior travam-se diariamente lutas e esforços no sentido da construção de contra-hegemonias.

Nesses espaços se desenrola a história da produção cultural. Aí a literatura se constitui como território em e de litígio, o território da luta pela hegemonia, aí onde a síntese entre o poder (tese) e luta contra o poder (antítese) está sempre sendo refeita.

Nas formações sociais burguesas (entendendo a história da Europa como a da formação de um bloco histórico), em que surgiu a literatura autônoma, a dialética base/ superestrutura se dá de maneira muito específica. A forma capitalista de produção é uma forma antagônica, porque repousa sobre a separação dos produtores das condições de produção. Os trabalhadores estão excluídos dos meios de produção e das mercadorias produzidas pelo seu trabalho. Como tal, a forma capitalista de produção supõe, contém e reproduz uma oposição e uma contradição objetivas entre as duas classes.

A "determinação das superestruturas pela infra-estrutura em última instância" é uma proposição central na hermenêutica marxista. Prestipino observa que entre a estrutura e as superestruturas há um movimento oscilatório que faz com que estas últimas possam ser reativas. Não se trata de uma concessão: ser ou não reativa tem a ver com o conjunto dos fenômenos sociais de um momento ou época. O significado da 
determinação (sempre usando determinar no sentido de apresentar os termos ou os términos, não no mero sentido de impor) só se torna inteligível no final do processo social, irregular e tortuoso, em última instância, pois. Esta é propriamente uma questão hermenêutica: o sentido estar no processo. (Prestipino, 1977, p. 46).

Daí, ainda segundo Prestipino, se pode deduzir: $1^{\circ}$ - que entre as estruturas e as superestruturas correspondentes há uma defasagem cronológica; $2^{\circ}$ - que a direção em que se produz a defasagem não tem um caráter unívoco, posto que nas superestruturas há funções que se atrasam e outras que se adiantam.

Podemos ver isso nas obras literárias. A defasagem cronológica entre as constantes infra-estruturais do Brasil dos anos 30, do momento do êxodo rural, e a forma literária urbana de Vidas secas é, sem dúvida, um “fato literário". Publicada em 1938, já quando a seca se esgotara como tema, Vidas secas encerra com chave de ouro um filão da literatura brasileira. Nisto se distingue de tantos outros livros sobre a seca. É uma obra "sobre" a literatura, sobre o trabalho literário. Pela forma, antecipa novos modos de organização social. (ver Bastos (2008).

No caso brasileiro, em que as constantes infra-estruturais já superadas nos países centrais ainda permanecem vivas, o intérprete tem pela frente uma situação, no mínimo, extravagante. Publicado em 1961, embora produzido ainda nos anos 50, "Meu tio o iauaretê" é uma arte de aderência às condições infra-estruturais semi-selvagens em que vive seu personagem. Mas não é uma idealização dessas condições nem do personagem. O autor identifica-se com o "pensamento selvagem" de Tonho Tigreiro, sua obra extravasa as fronteiras da representação tradicional, constrói-se como "selvagem" também. Mas não adere de todo, determina sua fronteira. "Meu tio o iauaretê" antecipa o extermínio, a partir de 1964, da mobilização rural.

$\mathrm{Na}$ história da arte o novo conteúdo se choca com a velha forma, requer uma forma nova. Na vida social, no sentido inverso, forças produtivas renovadas exigem renovação das relações de produção. Aí se dão as defasagens. Não é raro o novo conteúdo social se exprimir primeiro na arte do que na sociedade, embora sempre de modo conturbado ou como vaticínio, agouro, digamos.

O trabalho artístico é, assim, também conhecimento. Um tipo peculiar de conhecimento que Aristóteles chamou anagnórisis, ou a passagem do ignorar ao 
conhecer. Como observa Terence Cave (1988), anagnórisis é a sinédoque da literatura, porque a obra literária é por si mesma uma passagem da ignorância ao conhecimento. Uma forma de conhecimento que consiste em pôr em xeque, embora sem o desqualificar, o conhecimento lógico-racional. Aí onde há certeza, a literatura traz a dúvida, onde há luz, sombra. Mas também aí onde há sombra, traz luz. É um conhecimento que acolhe em si mesmo a dúvida, não se encerra, portanto, na certeza absoluta. Ao fazê-lo, porém, a obra literária não diz que o conhecimento é impossível ou que não há verdade, mas sim que a tensão verdade/ mentira é mediada pelas situações humanas. Daí a qualidade irrecusável da literatura enquanto coisa política. Ela abre-se ao mundo questionando as verdades estabelecidas, chamando a atenção para a ideologia das verdades ou as verdades da ideologia.

\section{A REPRESENTAÇÃO PROBLEMATIZADA: MODERNO/PÓS-MODERNO}

$\mathrm{O}$ ato de representação literária é uma forma de apropriação discursiva. Tem também a sua história e evolução. Historicizar a representação significa compreender as suas transformações na passagem do mundo pré-capitalista para o capitalista. Representar como apropriar pressupõe falhas e ligações entre o ato de representação e o mundo representado. A história, ainda nas palavras de Weimann, é uma constelação de atividades discursivas e não-discursivas, atividades, portanto, externas e internas ao texto.

Nas sociedades pré-capitalistas, a distância entre o ato poético de apropriação de um dado texto ou tema e a propriedade autoral é mínima. A matéria é dada, assim como as fontes, gêneros, padrões de intriga, figuras etc. A produção do poeta não atinge o status de propriedade individual. O significado e modo de produção são comunais.

$\mathrm{Na}$ ausência de divisões profundas entre aquele que apropria e aquilo que é apropriado, a função de representação permanece limitada. Na narrativa pré-moderna, a função de representação é mínima. Enquanto aquele que apropria se relaciona com seu objeto como, nas palavras de Marx, alguma "parte inorgânica da sua própria subjetividade", o uso da representação é restrito.

Mas, no início da modernidade, o processo de apropriação discursiva em forma representacional assume uma qualidade muito mais dinâmica e imprevisível. Sendo 
menos predeterminado pela propriedade comunal, pelos materiais culturais pré-dados, pelas convenções e tradições literárias, o ato de representação emerge sob situações em que o escritor é confrontado com a necessidade crescente de se apropriar dos significados e formas da produção literária. Ele tem que fazer isso porque confronta as condições e significados da produção e recepção literária como coisas alheias, como alguma coisa que ele não pode inquestionavelmente considerar como parte da existência do seu ser intelectual. Assim, a qualidade representativa da sua escrita e a própria função representativa problematizam-se.

Desde a Renascença, como observa Weimann, a dimensão de representatividade discursiva deixa de estar garantida, entra em estado de vulnerabilidade e imprevisibilidade que, paradoxalmente, faz a representação ao mesmo tempo problemática e necessária. O que a arte representacional pressupõe (e onde ela prospera) é a perda ou ruína da plenitude daquela propriedade em que o eu e a sociedade eram mutuamente engajados e em que esse engajamento era inquestionavelmente dado e garantido.

Os termos que aqui se relacionam são apropriação, representatividade e representação. Nas sociedades pré-modernas, quando o ato de apropriação é mínimo, a representatividade do escritor não está em questão, uma vez que o seu trabalho é também o trabalho comunal. Aí também não se problematiza a representação. No processo crescente em que o trabalho do escritor se desprende do trabalho comunal, perdendo a legitimidade prévia, se problematiza a representatividade. É nesse processo (que é o mesmo processo de autonomização da arte) que a representação, também agora problematizada, se faz necessária. Assim, segundo Weimann, a representação se tornou necessária, a partir da Renascença, no momento mesmo em que se fez problema.

A representação e as questões que ela suscita nunca saem de cena. Quanto mais se constroem estéticas não - ou anti-representacionais (para dar conta do cadáver incômodo da representação?), mais se evidencia que a representação continua ocupando um papel central no debate teórico e crítico. As estéticas não - ou anti-representacionais são, ao seu modo, formas de representação e talvez, no sentido mais positivista, isto é, no sentido de que re-produzem a ideologia dominante, a da sociedade que se vê como fora da História. Têm sua verdade inscrita naquilo mesmo que querem negar. 
Mas não é que neguem a representação, mas sim que para elas uma representação leva a outra representação que por sua vez leva a outra, e assim indefinidamente, sem que um grito ou uma lágrima corte o fio da clausura e ao mesmo tempo religue, num susto, o fio da vida. Nada haveria fora da representação, que assim seria uma espécie de prisão. Nesse sentido, para a hermenêutica dialética o importante é sair da prisão da representação, ir além dela. O realismo, no sentido amplo da palavra, é essa porta de saída da representação. Sublinhando o paradoxo, digamos que a representação realista reclama o mundo, abre a saída da clausura da representação.

O combate contra a representação teria o valor de um combate contra as chamadas metanarrativas que, pensados como se fossem da emancipação, seriam de fato formas de poder. Para se contrapor às metanarrativas, defendem os pós-modernistas a necessidade da proliferação dos micro-relatos. Como não é possível não representar, é preciso multiplicar as representações. Mas aqui se coloca, como assinala Prendergast (2000, p. 14), no mínimo um paradoxo: se nenhuma representação pode ser tomada como verdadeira, por oposição a outra que seria falsa, qual o sentido da multiplicação dos micro-relatos que combateriam os macro-relatos? Para que esse combate seja efetivo, é preciso que se os tome por verdadeiros, que se proceda à valoração e separação do verdadeiro do falso.

Os que negam a mimese, na verdade, pretendem defender a liberdade da literatura em se entregar àquilo que seria a sua essência: o direito de falar só de si mesma sem ter que prestar contas ao que quer que seja, senão a ela mesma. Seguramente, o pôr em xeque a referencialidade é o gesto de acinte de que brota a obra literária. Contudo, o pôr em xeque a referencialidade é mais criar alternativas de significado, ou significados alternativos, do que dizer que não há referencialidade, pois, se não há, como contraporse a ela? Sim, porque a liberdade da literatura só se dá por contraste com o mundo sem liberdade em que o significado é imposto.

\section{INTEPRETAÇÃO COMO APROPRIAÇÃO}

A apropriação é a luta por superar a distância cultural, a distância do próprio sentido ou, ainda, do sistema de valores sobre o qual o texto se organiza. (Ricoeur, 1970, p. 195) 
Ricoeur procura superar a dicotomia fundadora da Hermenêutica moderna, com Dilthey, entre explicar e compreender. Em Dilthey o objetivo era se contrapor ao paradigma das ciências da natureza que invadira as ciências humanas com o positivismo. Com o advento da moderna lingüística, porém, o paradigma da explicação surge dentro das próprias ciências humanas. Com a explicação estrutural chega-se à objetividade do texto, mas não se chega ainda à significação, o que só se dá com a interpretação.

Explicar e interpretar deixam de ser opostos para serem complementares, formando um único arc herméneutique. Assim, interpretar deixa de ser uma operação subjetiva sobre o texto para ser uma operação objetiva que seria o ato de texto. Retomando Aristóteles, diz ainda Ricoeur que a interpretação é interpretação pela linguagem e não sobre a linguagem. É o trabalho do sentido sobre ele mesmo. Com isso se supera o caráter psicologizante da interpretação: interpretar liga-se agora ao trabalho presente no texto.

A apropriação perde o seu caráter arbitrário, na medida em que é a retomada do que já está em obra, em trabalho, no texto. O dizer do hermeneuta é um redizer, que reativa o dizer do texto.

O texto não é apenas a fixação pela escrita da palavra oral, mas também inscrição na letra do que o discurso quer dizer. Assim compreendida, a obra produz uma verdadeira desordem nas relações entre a linguagem e o mundo e nas relações entre as subjetividades do autor e do leitor.

A desordem atinge a relação referencial da linguagem. Dirigindo-se a outro locutor, o sujeito do discurso oral diz qualquer coisa sobre qualquer coisa. Isto sobre o que ele fala é o referente do seu discurso. Pela referência a linguagem reenvia os signos ao mundo. Quando o texto toma o lugar da palavra, o movimento referencial é interceptado, o diálogo é interrompido pelo texto. Mas, interceptado não quer dizer suprimido. Caberá à interpretação efetuar a referência.

Com a interceptação da referência, o texto fica "no ar", fora do mundo ou sem mundo. Com isso todo texto fica livre para entrar em relação com outros textos que vêm tomar o lugar da realidade circunstancial mostrada pela palavra viva. Engendra-se, assim, o quase-mundo dos textos, isto é, a literatura. 
Essa desordem causa outra, a que ocorre na relação do texto com a subjetividade do autor e do leitor. Quando o texto toma o lugar da palavra, não há mais locutor. A proximidade do sujeito falante com relação a sua própria palavra é substituída pela relação complexa do autor com o texto que permite dizer que o autor é instituído pelo texto. Como se fosse o seu primeiro leitor.

Pela leitura, como apropriação, o texto ganha uma significação, o que não era possível apenas pela explicação estrutural. O leitor pode tanto prolongar aquela suspensão que afeta à referência quanto pode reativar o texto como palavra. Esta última atitude é a verdadeira destinação da leitura.

\section{Referências}

ANDRADE, Carlos Drummond de. Obra completa. Rio de Janeiro: Companhia José Aguilar, 1967.

ARISTÓTELES. Poética. Tradução, prefácio, introdução, comentário e apêndices de Eudoro de Sousa. Porto Alegre: Editora Globo, 1966.

ASOR ROSA, A. "Vanguarda". In Literatura-Texto. Enciclopédia Einaudi, vol. 17. Lisboa: Imprensa Nacional Casa da Moeda, 1989.

BANDEIRA, Manuel. Poesia completa e prosa. Rio de Janeiro: Companhia José Aguilar, 1967.

BASTOS, Hermenegildo. Inferno, alpercata: trabalho e liberdade em Vidas secas. Posfácio a Ramos, Graciliano. Vidas secas. Rio de Janeiro-São Paulo: Record, 2008.

CAVE, Terence. Recognitions: A Study in Poetics. New York: Oxford University Press, 1988.

EAGLETON, Terry. A ideología da estética. Rio de Janeiro: Jorge Zahar Editor, 1993.

FOUCAULT, Michel. O que é um autor. Lisboa: Edições 70, 1981.

GODELIER, Maurice. "Trabalho" in: Modo de produção. Desenvolvimento/ subdesenvolvimento. Enciclopédia Einaudi, vol. 7. Lisboa: Imprensa Nacional Casa da Moeda, 1986. 
GRAMSCI, Antonio. Il materialismo storico e la filosofia di Benedetto Croce. A cura di Valentino Gerratana. Roma: Editori Riuniti, 1975.

JAMESON, Frederic. $O$ inconsciente político. A narrativa como ato socialmente simbólico. São Paulo: Editora Ática, 1992.

Paulo: Hucitec, 1985.

Marxismo e forma. Teorias dialéticas da teoria no século XX. São

JAUSS, Hans Robert. El arte como anti-naturaleza. A propósito del cambio de orientación estética después de 1789. Villanueva, Darío. Avances en la teoría de la literatura. Universidad de Santiago de Compostela, 1994.

KOSELLEK, Reinhart, Gadamer, Hans-George. Historia y hermenéutica. Barcelona: Paidós, 1997.

LEFEBVRE, Henri. A linguagem e a sociedade. Lisboa: Ulisséia, s/d.

LUKÁCS, Georg. Estetica. Vol. 2. I - La peculiaridad de lo estético. I-Problemas de la mímesis. Barcelona/ México: Grijalbo, 1972.

Ontología del ser social. El trabajo. Buenos Aires: Herramienta, 2004.

MARX, Karl. El capital. Crítica de la economía politica. México: Fondo de Cultura Económica, vol. I, 1986.

Editor, 1970.

. Contribuición a la crítica de la economía política. Madrid: Alberto Corazón

. La ideología alemana. Buenos Aires: Ediciones Pueblos Unidos, 1973.

. Manuscritos económico-filosóficos. São Paulo: Boitempo Editorial, 2004.

PRAWER, S. S. Karl. Marx and world literature. Oxford, New York, Melbourne: Oxford University Press, 1978.

PRENDERGAST, Christopher. The Triangle of Representation. New York: Columbia University Press, 2000.

PRESTIPINO, Gisuppe. El pensamiento filosófico de Engels. Naturaleza y sociedad en la perspectiva teórica marxista. México: Siglo Veintiuno Editores, 1977.

El marxismo y la investigación teórica sobre el arte literario. In: Barberis, Pierre et alli. Literatura e ideologías. Madrid: Alberto Corazón Editor, 1972.

RANCIERE, Jacques. L'inconscient esthétique. Paris: Galilée, 2001. 
RICOEUR, Paul. Qu'est-ce qu'un texte? Expliquer et Comprendre. Bubner, Rüdiger, Cramer, Konrad, Wiehl, Reiner. Hermeneutik und Dialektik. Aufsätze II. Tübingen: J.C.B Mohr, 1970.

Vázquez, Adolfo Sánchez. As idéias estéticas de Marx. Rio de Janeiro: Editora Civilização Brasileira, 1968.

Weimann, Robert. Text, Author-Function and Society: Towards a Sociology of Representation and Apropriation in Modern Narrative. In: Collier, Peter, Geyer-Ryan, Helga. Literary Theory Today. Cambridge: Polity Press, 1992.

. "Apropriation" and Modern History in Renaissance Prose Narrative. New Literary History, vol. XIV, Spring 1983, Number 3.

Structure and Society in Literary History. Baltimore and London: The John Hopkins University Press, 1984.

Williams, Raymond. Marxismo e literatura. Rio de Janeiro: Zahar Editores, 1979. . Culture and Materialism. London-New York, 2005. . Palavras-chave. São Paulo: Boitempo, 2007. 